\title{
HUKUMAN PEMBUNUHAN \\ DALAM HUKUM PIDANA ISLAM DI ERA MODERN
}

\section{Rokhmadi}

Fakultas Syari'ah dan Hukum Universitas Islam Negeri Walisongo Semarang Email: rokhmadi66@yahoo.com

\begin{abstract}
Murder in the Islamic criminal law including jarimah qishas-diyat, namely jarimah punishable by qishas (punishment commensurate/proportional) or punishment diyat (fines/restitution), the specified limits his sentence, but is categorized as a right adami (buman/individual), in which the victim or his family can forgive the perpetrators, so that the penalty (qishas-diyat) can remove altogether, because in qishas no entitlements for victims' families to act as "institutions forgiving", they can ask for their right to forgive or not forgive the criminal act. According to scholars' Salaf that the policy of punishment given is based on the viewpoint of the habit of Arab society that never applies to the Muslim community early, namely regarding who is authorized to determine the wisdom qishas or of diyat is heavily influenced by the practice habits of Arab society in the 7 th century $M$, both about social status, as well as the local culture, the sunnah and the practice run early Muslims who provide input or benchmarks in detail the principles prinsp Islamic criminal law (jinayat), so that in determining the sentence still is discrimination, whether social status, gender and religion. Therefore, in the modern era according to scholars' khalaf that sentencing for murder should be equated between the murder of men with women, killing of Muslims by non-Muslims, the murder of a father with his son, should remain punishable qishas and diyat amount laki-men with diyat amount for women should be equal, so that the position of human beings are equal before the law (there is no discrimination; social status, gender and religion.
\end{abstract}

Keywords: Islamic Criminal Law, murder, and equality law

\begin{abstract}
Abstrak
Pembunuhan dalam hukum pidana Islam termasuk jarimah qishasdiyat, yaitu jarimah yang diancam dengan hukuman qishas (hukuman sepadan/sebanding) atau hukuman diyat (denda/ganti rugi), yang sudah ditentukan batasan hukumannya, namun dikategorikan sebagai hak adami (manusia/perorangan), di mana pihak korban ataupun keluarganya dapat memaafkan pelaku, sehingga hukuman (qishas-diyat) bisa hapus sama sekali, karena dalam qishas ada pemberian hak bagi keluarga korban untuk berperan sebagai 'lembaga pemaaf', mereka bisa meminta haknya untuk memaafkan atau tidak memaafkan terhadap perbuatan pelaku tindak pidana. Menurut ulama' salaf bahwa kebijakan hukuman yang diberikan
\end{abstract}


adalah berdasarkan sudut pandang kebiasaan masyarakat Arab yang pernah berlaku pada masyarakat Muslim awal, yaitu mengenai siapa yang diberi wewenang untuk menentukan kebijaksanaan qishas atau mengenai diyat adalah sangat dipengaruhi oleh praktek kebiasaan masyarakat Arab pada abad ke-7 M, baik mengenai status sosial, maupun budaya setempat, maka sunnah dan praktek yang dijalankan Muslim awal ini yang memberikan masukan atau tolok ukur secara rinci terhadap prinsip-prinsp hukum pidana Islam (jinayat), sehingga dalam penetapan hukumannya masih bersifat diskriminasi, baik status social, gender dan agama. Oleh karena itu, di era modern menurut ulama' khalaf bahwa penetapan hukuman bagi pembunuhan harus disamakan antara pembunuhan laki-laki dengan perempuan, pembunuhan orang Muslim dengan non-muslim, pembunuhan seorang ayah dengan anaknya, harus tetap dikenai hukuman qishas dan jumlah diyat laki-laki dengan jumlah diyat untuk perempuan harus sama, sehingga posisi manusia adalah sama di depan hukum (tidak ada lagi diskriminasi; status sosial, kesetaraan gender dan agama.

Kata kunci: Hukum Pidana Islam, pembunuhan, dan kesamaan hukum

\section{A. Pendahuluan}

Pembunuhan dalam hukum pidana Islam termasuk jarimah qishasdiyat, yaitu jarimah yang diancam dengan hukuman qishas (hukuman sepadan/sebanding) atau hukuman diyat (denda/ganti rugi), yang sudah ditentukan batasan hukumannya, namun dikategorikan sebagai hak adami (manusia/perorangan), di mana pihak korban ataupun keluarganya dapat memaafkan si pelaku, sehingga hukuman (qishas-diyat) tersebut bisa hapus sama sekali. Karena dalam qishas ada pemberian hak bagi keluarga korban untuk berperan sebagai "lembaga pemaaf', mereka bisa meminta haknya untuk memaafkan atau tidak memaafkan terhadap perbuatan pelaku tindak pidana (restoratif) ${ }^{1}$. Dalam hal ini disebut dengan keadilan retributiverestitutive, dan jarimah ta'zir juga tidak dikategorikan sebagai hak Allah, karena hukumannya ditetapkan oleh pemegang kebijakan (ولى الأمر).

\footnotetext{
1 Restoratif yaitu hak korban atau walinya/keluarganya untuk memberikan pemaafan/ pengampunan kepada pelaku tindak pidana, dan dengan prinsip inilah sesungguhnya yang menjadi landasan syari’at Islam sebagaimana isi yang terkandung dalam QS. al-Baqarah (2): 178.

2 Retributive yaitu pidana merupakan akibat mutlak yang harus ada sebagai suatu pembalasan kepada orang yang melakukan kejahatan (pembalasan setimpal). Menurut Johannes Andenaes sebagaimana dikutip oleh Muladi dan Barda Nawawi Arief bahwa tujuan utama dari pidana ialah untuk memuaskan tuntutan keadilan (to satisfy the claims of justice). Lihat Muladi dan Barda Nawawi Arief, 2005, Teori-Teori dan Kebijakan Pidana, Bandung; PT. Alumni, hlm. 10-11. Sedangkan restitutive yaitu adanya kesempatan untuk
} 
Akan tetapi menurut Khallaf pemerintah masih berhak untuk memberikan hukuman ta'zir, jika pelakunya dimaafkan oleh korban (keluarga korban). ${ }^{3}$ Demikian pula menurut Madzhab Maliki yang mewajibkan pemberian hukuman ta'zir bagi pelaku pembunuhan dan penganiayaan yang hukuman qishash dihapuskan atau yang terhalang hukumannya. ${ }^{4}$

Menurut 'Audah hukuman qishas dijatuhkan pada jarimah al-qatl al'amd dan al-jarh al-'amd yang telah memenuhi persyaratan dan pelaku tidak dimaafkan oleh pihak korban. Sedangkan hukuman diyat dijatuhkan pada jarimah al-qatl syibh al- 'amd, al-qatl al-khata', dan al-jarh al-khata.' 'Termasuk juga dalam keadaan qishas tidak bisa dilaksanakan, misalnya, meninggalnya pelaku tindak pidana, hilangnya anggota badan pelaku yang akan di-qishas, taubatnya pelaku, perdamaian, pengampunan, diwariskan hak qishas, atau kedaluwarsa masa hukumannya, ${ }^{6}$ maka pelaku bisa dijatuhi hukuman diyat dan ta'zir untuk kemaslahatan umum. Justru madzhab Maliki mewajibkan hukuman ta'zir untuk hukuman qishas yang gugur atau terhalang baik terhadap pembunuhan dan penganiayaan. ${ }^{7}$

Demikian pula, jika pihak korban memaafkan pelakunya, maka hukuman qishas sebagai hukuman pokok (al-'uqubah ashliyah) menjadi gugur dan diganti dengan diyat sebagai hukuman pengganti (al-'uqubah albadaliyah), sementara pemegang otoritas (ولى الأمر) bisa menjatuhkan hukuman ta'zir yang sesuai dengan perbuatan pelaku tindak pidana. Sedangkan pada tindak pidana semi sengaja dan tidak sengaja, maka hukuman pokoknya yaitu diyat. Meskipun diyat merupakan hukuman, namun hukuman diyat seluruhnya diserahkan kepada pihak korban atau walinya, jadi diyat atau ganti rugi tersebut tidak masuk ke kas negara. Dari sisi ini diyat lebih menyerupai pengganti kerugian yang diderita pihak korban (تعويض) yang besarnya berbeda-beda sesuai dengan kerugian akibat

memberikan maaf dan kemungkinan terjadinya rekonsiliasi adalah sebagai prinsip dasar dari qishas, lihat, Abu Hafsin, 2010, Kontribusi Konsep Keadilan Hukum Pidana Islam Terbadap Pengembangan Konsep Keadilan Hukum Pidana Positif, Semarang: IAIN Walisongo, hlm. 82.

${ }^{3}$ Khallaf, 'Abd al-Wahhab, 1972, Tlmu Ushul al-Figh, Jakarta-Indonesia: al-Majlis al-'Ala al-Indonesi li al-Da'wah al-Islamiyyah, hlm. 2015.

4 'Audah, 'Abd al-Qadir, 2011, Al-Tasyri' al-jina'i al-Islami Muqaranan bi Qanun al-Wadl', Juz I, Beirut-Libanon: Dar al-Kutub al-'Ilmiyyah, hlm. 541.

5 'Audah, 'Abd al-Qadir, 2011, Al-Tasyri'...op cit, hlm. 538-541.

${ }^{6}$ Ibid., hlm. 624.

${ }^{7}$ Ibid., hlm. 541. 
pembunuhan atau penganiayan yang diderita korban. Akan tetapi, di sisi lain diyat tetap merupakan hukuman yang jika dimaafkan oleh pihak korban bisa diganti dengan hukuman ta'zir, karena itu dapat dikatakan bahwa diyat merupakan hukuman (عقبة) dan pengganti kerugian (تعويض) sekaligus. ${ }^{8}$

Kemudian, ketentuan mengenai kriteria jarimah qishas-diyat yang masih menjadi perdebatan adalah mengenai prinsip kesamaan di depan hukum (keadilan sosial), kesetaraan gender dan adanya diskriminasi agama harus dikonstruksi lagi. Sebagai contoh adalah jumlah diyat pembunuhan terhadap seorang perempuan yang semula ditetapkan setengah dari diyat laki-laki, ${ }^{9}$ harus disamakan dengan jumlah diyat laki-laki, diyat pembunuhan seorang non-muslim, harus disamakan dengan diyat seorang muslim, dan seorang muslim yang membunuh non-muslim, harus tetap dikenai hukuman qishas. ${ }^{10}$

Hal ini sebagaimana pendapat jumbur fuqaha' yang menetapkan bahwa hukuman qishas dapat diberlakukan kepada pelaku, jika telah memenuhi syarat-syarat yang berkaitan dengan korban, yaitu;

1. Korban (orang yang terbunuh) harus orang yang dilindungi keselamatannya (darahnya) (ma'shum al-dam) oleh Negara. Dengan demikian, jika korban kehilangan keselamatannya, seperti; murtad, pezina mubshan, pembunuh, pemberontak, maka pelaku pembunuhan tidak dapat dikenai hukuman qishas. Sebagaimana hadits riwayat Muslim:

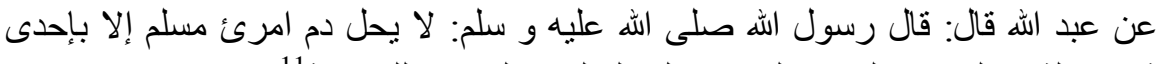

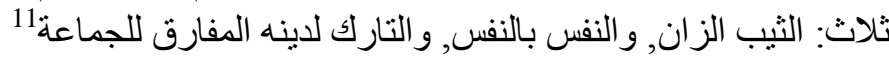

Artinya: Dari 'Abdillah berkara: Rasulullah saw. bersabda: "Tidak balal darah seorang muslim, kecuali karena tiga perkara; orang yang mubshan berzina, atau orang yang membunuh jiwa karenanya ia harus dibunuh, atau orang yang meninggalkan agamanya (murtad) dan berpisah dari jamaahnya".

Dan berdasarkan Hadits yang diriwayatkan al-Bukhari dari Ibnu 'Abbas;

\footnotetext{
8 Ibid., hlm. 542.

9 Al-Kahlani, Muhammad bin Ismacil, t.th., Subul al-Salam, Syarh Bulugh al-Maram: min Adilah al-Ahkam, Juz III, Beirut: Dar al-Fikr, hlm. 250.

10 Ridho, Achmad Ainur, 2010, Hermeneutika Qur'an Versi Amina Wadud Muhsin, dalam Hermenentika al-Qur'an dan Hadits, editor; Sahiron Syamsuddin, Yogyakarta: elSAq Press, hlm. 183.

11 Muslim, 1983, Shahih Muslim, Juz III, Beirut-Libanon: Dar al-Fikr, hlm. 1302-1303.
} 
عن ابن عباس رضي الله عنهما قال: قال رسول الله صلى الله عليه و سلم: من بدل دينه

Artinya: Dari Ibnu 'Abbas ra., berkata; Rasulullah saw. bersabda: "Barangsiapa mengganti agamanya (keluar dari agama Islam/murtad), maka bunublab ia".

2. Korban tidak bagian dari pelaku pembunuhan. Maksudnya, antara keduanya tidak ada hubungan darah antara anak dan bapak. Dengan demikian, jika ayah membunuh anaknya, maka tidak dapat dihukum qishas. ${ }^{13}$ Alasannya, berdasarkan hadits yang diriwayatkan al-Tirmidzi dan al-Kahlani:

عن عمر بن الخطاب قال: سمعت رسول الله صلى الله عليه و سلم يقول:لا يقاد الوالد

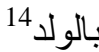

Artinya: Dari 'Umar bin al-Khaththab berkata; saya mendengar Rasulullah saw. bersabda: "tidak diqishas orang tua yang membunuh anaknya".

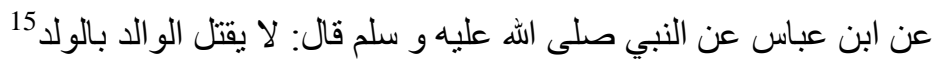
Artinya: Dari Ibnu 'Abbas dari Nabi saw. bersabda: "Tidak dibunuh orang tua yang membunub anaknya".

Dan hadits yang diriwayatkan Ibnu Majah:

عن عبد الله ابن عمرو قال: قال رسول اله صلى الله عليه و سلم: أنت و مالك لأبيك3 16 Artinya: Dari 'Abdillah Ibnu 'Amru berkata: Rasulullah sawn. bersabda: "Kamu dan bartamu itu adalah milik. bapakmu".

3. Korban harus sederajat (keseimbangan) dengan pelaku, baik agama, kemerdekaan, maupun jenis kelamin. Dengan demikian, jika korban itu sebagai budak, atau non muslim (kafir), dan atau perempuan, kemudian pelakunya adalah merdeka, muslim dan laki-laki, maka tidak dapat dihukumi qishash. Jumbur fuqaha' berpendapat bahwa asas perlindungan adalah keislaman, kecuali mereka yang melakukan perjanjian (kafir drimmi/mu'ahad) dan yang terlindungi darahnya (معصوم الدم) yang

\footnotetext{
12 Al-Bukhari al-Ja'fy, Imam Abi 'Abdillah Muḥammad bin Isma'il Ibn Ibrahim bin alMughirah bin Bardzabah, 1992, Shahih al-Bukhari, Juz VIII, Beirut-Libanon : Dar alKutub al-'Tlmiyyah, hlm. 372.

13 'Audah, 'Abd al-Qadir, 2011, Al-Tasyri'...op cit, Juz II, hlm. 93.

${ }^{14}$ Al-Tirmidzi, Abi 'Isa Muḥammad bin 'Isa bin Saurah, t.th., al-Jami' al-Shahih , Juz IV, Beirut-Libanon: Dar al-Kutub al-'Ilmiyyah, hlm. 12.

15 Al-Kahlani, th., Subul al-Salam, op cit, hlm. 233.

${ }^{16}$ Ibn Majah, Abi 'Abdillah Muhammad bin Yazid al-Qazwini, t.th., Sunan Ibnu Majah, Juz II, Beirut: Dar al-Fikr, hlm. 769.
} 
paling tinggi adalah muslim itu sendiri. ${ }^{17}$. Alasan jumhur adalah hadits yang diriwayatkan oleh Abu Dawud, al-Tirmidzi dan al-Kahlani;

عن عمرو بن شعيب عن أبيه عن جده عن النبى صلى الله عليه وسلم قال: لا يقتل مؤمن بكافر عis 18

Artinya: Dari 'Amru bin Syu'aib dari ayahnya dari kakeknya dari Nabi Muhammad saw. bersabda: "Seorang muslim tidak boleh dibunuh (diqishas), karena membunuh seorang kafir".

Berdasarkan uraian di atas, bahwa penetapan hukuman qishas menurut pendapat jumbur fuqaha' untuk zaman sekarang ini tidak tepat, karena menimbulkan berbagai macam permasalahan, baik berkaitan dengan persamaan hak seseorang dimuka hukum, prinsip-prinsip keadilan dan nilai-nilai kemanusiaan dalam hak asasi manusia.

Oleh karena itu, pendapat jumbur fuqaba' sangat perlu untuk direkonstruksi, agar tidak menimbulkan kesan bahwa hukum Islam itu kaku, statis, dan tidak fleksibel, sehingga semua bentuk diskriminasi harus dihapuskan agar ketentuan hukum pidana Islam dapat memenuhi keadilan, tuntutan konstitusional dan HAM di dunia modern.

\section{B. Hukuman Qishas menurut Ulama' Salaf \\ 1) Pengertian Qishas}

Qishas dalam bahasa Arab adalah تتبع الأثر, artinya, menelusuri jejak, ${ }^{19}$ atau (مقتص (الأثر), artinya, pencari jejak. ${ }^{20}$ Pengertian tersebut digunakan untuk arti hukuman, karena orang yang berhak atas qishas mengikuti dan menelusuri tindak pidana terhadap pelaku. Qishas juga diartikan: المماثلة artinya, keseimbangan dan kesepadanan. ${ }^{21}$

Dari pengertian kedua inilah, kemudian diambil pengertian qishas menurut istilah. Menurut istilah, qishas ialah memberikan balasan

17 'Audah, 'Abd al-Qadir, 2011, Al-Tasyri'...op cit, Juz II, hlm. 97-99.

${ }^{18}$ Dawud, al-Imam al-Hafidz al-Muṣannif al-Mutqan Abi Dawud Sulaiman ibn al-Asy'ás al-Sajastanī al-Azdi, 1988, Sunan Abi Dawud, Juz IV, t.tp.: al-Dar al-Mișriyyah alLibaniyyah, hlm. 71. Lihat al-Tirmidzi, Abi 'Isa Muhammad bin 'Isa bin Saurah, t.th., alJami' al-Shahih, Juz IV, Beirut-Libanon: Dar al-Kutub al-'Ilmiyyah, hlm. 17. Dan lihat juga Al-Kahlani, t.th., Subul al-Salam, op cit, hlm. 233.

${ }^{19}$ Unais, Ibrahim, et.al, t.th. al-Mu'jam al-Wāsiț, Juz II, t.tp.: Dār Ihya at-Turās al-'Arabī, hlm. 739 .

${ }^{20}$ Munawwir, Aḥmad Warsūn, 1997, al-Munawwir, op cit, hlm. 1126.

21 Az-Zuhaili, Wahbah, 2002, Al-Figh al-Islami wa Adilatubu, Juz VII, Damaskus: Dar alFikr, hlm. 5661. 
kepada pelaku sesuai dengan perbuatannya, yaitu membunuh ( مجازاة 2. الجانى بمثل فعله, و هو القتل

Ibrahim Unais memberikan definisi berikut ini;

$$
\text { القصاص هو أن يوقع على الجانى مثل ماجنى } 23
$$

Artinya: Qishas yaitu menjatubkan bukuman kepada pelaku persis/sama seperti apa yang dilakukannya.

Sedangkan menurut Abū Zahrah, qishas adalah memberikan hukuman kepada pelaku perbuatan seperti apa yang dilakukan terhadap korban. ${ }^{24}$

\section{2) Dasar Hukuman Qishas}

Hukuman qishas disyari'atkan berdasarkan al-Qur'ān, al-Sunnah dan Ijmā'.

1) Qishas berdasarkan al-Qur'ān di antaranya;

a) QS. al-Baqarah (2): 178-179;

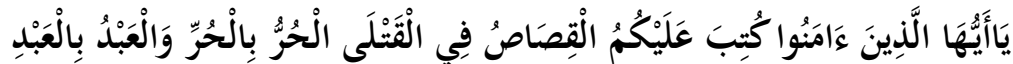

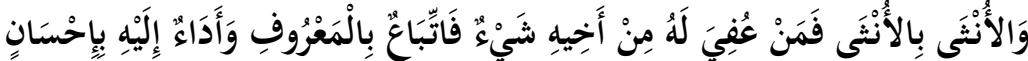

$(178$

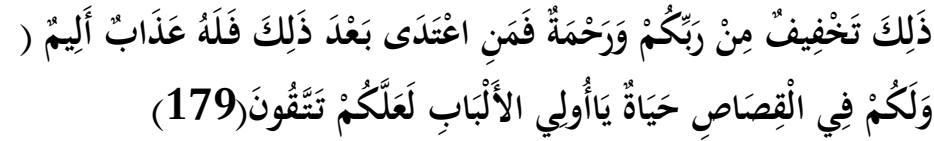

Artinya: Hai orang-orang yang beriman, diwajibkean atas kamu qishas berkenaan dengan orang-orang yang dibunub; orang merdeka dengan orang merdeka, hamba dengan hamba, dan wanita dengan wanita, maka barangsiapa yang mendapat suatu pemaafan dari saudaranya, bendaklah (yang memaafkan) mengikuti dengan cara yang baik, dan bendaklah (yang diberi maaf) membayar (diyat) kepada yang memberi maaf dengan cara yang baik (pula), yang demikian itu adalah suatu keringanan dari Tuhan kamu dan suatu rahmat, barangsiapa yang melampaui batas sesudah itu, maka baginya siksa yang sangat pedih. Dan dalam qishas itu ada (jaminan kelangsungan) bidup bagimu, hai orang-orang yang berakal, supaya kamu bertakwa (Depag RI, 1971: 43-44).

b) QS. al-Māidah (5): 45;

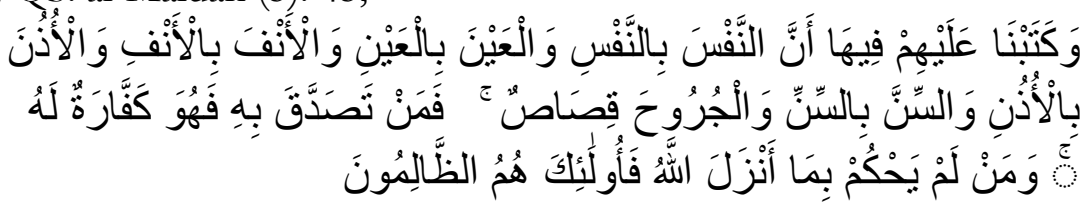

\footnotetext{
22 Ibid.

${ }^{23}$ Unais, Ibrahim, et.al, t.th. al-Mu'jam al-Wäsit, loc cit, hlm. 740.

${ }^{24}$ Zahrah, al-Imām Muḥammad Abū, t.th., al-Uqübah, op cit, hlm. 335.
} 
Artinya: Dan Kami telah tetapkan terhadap mereka di dalamnya (al-Taurat) bahwasanya jiwa (dibalas) dengan jiwa, mata dengan mata, hidung dengan hidung, telinga dengan telinga, gigi dengan gigi, dan luka luka (pun) ada qishasnya, barangsiapa yang melepaskan (hak qishas)nya, maka melepaskan hak itu (menjadi) penebus dosa baginya, barangsiapa tidak memutuskan perkara menurut apa yang diturunkan Allah, maka mereka itu adalah orang-orang yang zalim (Depag RI, 1971: 167).

2) Qishas berdasarkan al-Sunnah/al-Hadits, di antaranya;

a). Hadits riwayat Muslim:

عن عبد الله قال: قال رسول الله صلى الله عليه و سلم: لا يحل دم امرئ مسلم إلا

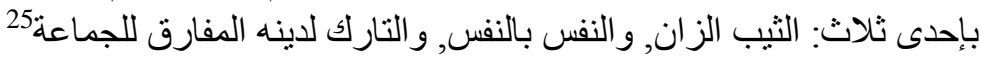
Artinya: Dari 'Abdillāh berkara: Rasūlullāh saw. bersabda: "Tidak halal darah seorang muslim, kecuali karena tiga perkara; orang yang mubshan berzina, atau orang yang membunuh jiwa karenanya ia harus dibunuh, atau orang yang meninggalkan agamanya dan berpisab dari jamaabnya".

b). Hadits riwayat Abu Dawud:

عن ابن عبيد قال: قال رسول الله صلى الله عليه و سلم: ومن قتل عمدا فهو قود26 Artinya: Dari Ibnu 'Ubaid berkata, Rasulullah saw. bersabda: "Dan barangsiapa dibunuh dengan sengaja, ia berhak untuk menuntut qishas".

\section{3) Syarat-Syarat Hukuman Qishas Menurut Ulama' Salaf}

Hukuman qishas tidak dapat dilaksanakan, jika syarat-syaratnya tidak terpenuhi. Syarat-syarat tersebut baik untuk pelaku pembunuhan (القاتل), korban yang dibunuh (المقتل), perbuatan pembunuhannya (القتول) dan wali dari korban (ولى القتيل).

Adapun syarat-syaratnya adalah sebagai berikut:

1) Syarat-Syarat Pelaku (القاتل)

Syarat-syarat yang harus dipenuhi oleh pelaku untuk dapat diterapkan hukuman qiṣạs menurut az-Zuhạili ada 3 (tiga) macam, ${ }^{27}$ yaitu;

a) Pelaku harus orang mukallaf, yaitu balig dan berakal.

Dengan demikian, hukuman qishas tidak dapat dijatuhkan terhadap anak yang belum balig dan orang gila. Berdasarkan Hadits riwayat al-Bukhari, Abu Dawud dan at-Tirmiżi di bawah ini:

\footnotetext{
${ }^{25}$ Muslim, 1983, Șahị Muslim, Juz III, op cit, hlm. 1302-1303.

${ }^{26}$ Dawud, al-Imam al-Ḥafiz al-Mușannif al-Mutqan Abi Dawud Sulaiman ibn al-Asy'ás as-Sajastani al-Azdi, 1988, Sunan Abi Dawud, Juz IV, t.tp.: al-Dar al-Mișriyyah alLibaniyyah, 182.

27 Az-Zuhaili, Wahbah, 2002, Al-Figh al-Islami, op cit, hlm. 5665-5666.
} 
عن على أن رسول الله صلى الله عليه وسلم قال: رفع القلم عن ثناثة: عن النائم

حتى يستيقط, و عن الصبي حنى يدرك (يشب, يكبر), و وعن المجنون حتى يفيق

28 (يعقل, بيرأ)

Artinya: Dari 'Ali Babwasannya Rasulullah saw. bersabda: "Dibebaskan ketentuan bukum dari tiga perkara: orang yang tidur sampai bangun, anak-anak sampai ia dewasa, dan orang yang gila sampai ia sembub”.

b) Pelaku melakukan pembunuhan dengan sengaja

Menurut jumbur bahwa pelaku yang melakukan pembunuhan menghendaki (adanya niat) hilangnya nyawa, tetapi menurut Mālik tidak mensyaratkan adanya niat melainkan hanya mensyaratkan kesengajaan dalam melakukannya. Alasan jumbur adalah hadits yang berbunyi:

$$
\text { العمد قود إلّا أن بعفو ولي المقتول }
$$

Artinya: Pembunuhan sengaja itu harus diqishas, kecuali jika wali korban memberikan pengampunan.

c) Pelaku harus orang yang mempunyai kebebasan.

Syarat ini dikemukakan oleh Hanafiyyah yang mengatakan bahwa orang yang dipaksa melakukan pembunuhan tidak dapat diqishas, tetapi menurut jumbur bahwa orang yang dipaksa untuk melakukan pembunuhan tetap harus dihukumi qishas.

2) Syarat-Syarat untuk Korban (المقتول)

Penerapan hukuman qishas kepada pelaku harus memenuhi syarat-syarat yang berkaitan dengan korban, menurut az-Zuhaili ada 3 (tiga) macam, ${ }^{29}$ yaitu;

1) Korban (orang yang terbunuh) harus orang yang dilindungi keselamatan darahnya (معصوم الدم) oleh Negara.

Dengan demikian, jika korban kehilangan keselamatannya, seperti; murtad, pezina muhshan, pemberontak, maka pelaku pembunuhan tidak dapat dikenai hukuman qishas. Sebagaimana Hadits riwayat Muslim di atas.

2) Korban tidak bagian dari pelaku pembunuhan.

Maksudnya, antara keduanya tidak ada hubungan darah antara anak dan bapak. Dengan demikian, jika ayah membunuh

28 Al-Bukhari al-Ja'fy, 1992, Șhihh al-Bukhari, Juz VIII, op cit, hlm. 336. Lihat Dawud, 1988, Sunan Abi Dawud, op cit, hlm. 1137-139. Dan lihat juga Al-Tirmiżi, t.th., al-Jami‘ așSahih, op cit, hlm. 24.

${ }^{29}$ Az-Zuhaili, Wahbah, 2002, Al-Fiqh al-Islami, Juz VII, op cit, hlm. 5666-5669. 
anaknya, maka tidak dapat dihukum qishas. Ini adalah pendapat jumbur yang diikuti oleh 'Audah. ${ }^{30}$ Alasannya, berdasarkan Hadits riwayat at-Tirmizi, al-Kahlani dan Ibnu Majah:

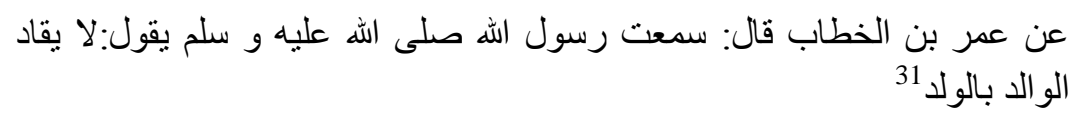

Artinya: Dari Umar bin al-Khattab berkata; saya mendengar Rasulullah saw. bersabda: "Tidak diqishas orang tua yang membunuh anaknya".

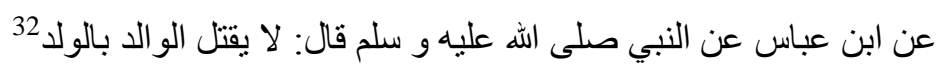

Artinya: Dari Ibnu 'Abbäs dari Nabi saw. bersabda: "Tidak dibunuh orang tua yang membunuh anaknya".

لأبيك333 عند الله ابن عمرو قال: قال رسول الله صلى اله عليه و سلم: أنت و مالك

Artinya: Dari 'Abdillah Ibnu 'Amru berkata: Rasulullah saw. bersabda: "Kamu dan hartamu itu adalab milike bapakmu".

Menurut Imam Malik, ayah yang membunuh anaknya dengan sengaja harus tetap dihukumi qishas, kecuali tidak ada kesengajaan, karena melakukan pengajaran. ${ }^{34}$

3) Korban harus sederajat (keseimbangan/التكافؤ) dengan pelaku, baik Islam maupun kemerdekaan.

Dengan demikian, jika korban itu sebagai budak, atau non muslim (kafir), kemudian pelakunya adalah merdeka dan muslim, maka tidak dapat dihukumi qishas. Ini adalah pendapat jumbur berpendapat bahwa asas perlindungan (العصمة) adalah keislamannya, kecuali mereka yang melakukan perjanjian (kafir żimmi/mu'ahad) dan yang terlindungi darahnya (معصوم الدم) yang paling tinggi adalah keislamannya (muslim) itu sendiri. Pendapat inilah yang diikuti juga oleh 'Audah. ${ }^{35}$ Alasan jumbur adalah Hadits riwayat al-Bukhari, Abu Dawud, al-Tirmizi dan alKahlani:

\footnotetext{
30 'Audah, 'Abd al-Qadir, 2011, At-Tasyri' al-jinai, Jilid II, op cit., hlm. 93.

${ }^{31}$ Al-Tirmizi, t.th., al-Jami' aș-Sahih, Juz IV, op cit, hlm. 12.

32 Al-Kahlani, t.th., Subul as-Salam, op cit, hlm. 233.

${ }^{33}$ Ibnu Majah, t.th., Sunan Ibnu Majah, Juz II, Mesir: Dar al-Fikr hlm. 769.

34 Ibnu Rusyd, al-Imam Abi al-Walid Muhammad bin Aḥmad bin Muḥammad bin Aḥmad bin Rusyd al-Qurțubi, 1988, Bidayah al-Mujtabid Wa Nihayah al-Muqtașid, Juz II, Beirut-Libanon: Dar al-Kutub al-'Tlmiyyah, hlm. 401.

35 'Audah, 'Abd al-Qadir, 2011, At-Tasyri' al-Jinai, Jilid II, op cit., hlm. 97-99.
} 
مؤمن/مسلم بكافرو بن شعيب عن أبيه عن جده عن النبى صلى الله عليه وسلم قال: لا يقتل

Artinya: Dari 'Amru bin Syu'aib dari ayahnya dari kakeknya dari Nabi saw. bersabda: "Seorang mukmin/muslim tidak boleh dibunuh (diqishas), karena membunuh seorang kafir".

Hadits tersebut dikuatkan oleh Hadits riwayat Abu Dawud:

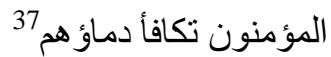

Artinya: Orang-orang mukmin itu sederajat darahnya.

Menurut Hanāfiyyah tidak mensyaratkan keseimbangan dalam kemerdekaan dan agama. Alasannya adalah keumuman ayat alQur'an tentang qishas yang tidak membeda-bedakan antara jiwa dengan jiwa yang lain, yaitu QS. al-Maidah (5): 45 dan al-Baqarah (2): 178 .

3) Syarat-syarat untuk Perbuatan Pembunuhan (القتل) harus Langsung • Persyaratan ini adalah menurut Hanāfiyyah yang berpendapat bahwa pelaku disyaratkan perbuatan pembunuhan itu harus perbuatan langsung (مباشرة), bukan perbuatan tidak langsung (تسبّب), jika perbuatannya tidak langsung, maka hukumannya diyat, tidak qishas, karena perbuatan pembunuhan tidak langsung termasuk pembunuhan semi sengaja atau tidak sengaja. Contohnya, jika orang membuat sumur kemudian ada orang jatuh ke dalamnya lalu ia mati karenanya, maka si pembuat sumur tidak dapat dikenakan hukuman qishas, tetapi hanya diyat.

Menurut jumbur tidak mensyaratkan masalah ini, alsannya bahwa pembunuhan tidak langsung juga dapat dikenakan hukuman qishas, seperti pembunuhan langsung. ${ }^{38}$

4) Syarat-Syarat Wali (Keluarga) Korban (ولى القتيل).

Hanafiyyah mensyaratkan bahwa wali dari korban yang memiliki hak qishas harus jelas diketahui, jika wali korban tidak diketahui, maka hukuman qishas tidak dapat dilaksanakan, tetapi fuqaha’ lainnya tidak mensyaratkannya. ${ }^{39}$

\footnotetext{
36 Al-Bukhari al-Ja'fy, 1992, Șahih al-Bukhari, Juz VIII, op cit, hlm. 365. Lihat Dawud, 1988, Sunan Abi Dawud, Juz IV, op cit, hlm. 171. Lihat atTirmizi, t.th., al-Jami aṣ-Ṣahih, Juz IV, op cit, hlm. 17. Dan lihat Al-Kahlani, t.th., Subul as-Salam, op cit., hlm. 233.

${ }^{37}$ Dawud, 1988, Sunan Abi Dawnd, Juz IV, op cit, hlm. 179.

38 Az-Zuhaili, Wahbah, 2002, Al-Fiqh al-Islami, Juz VII, op cit, hlm. 5674.

${ }^{39}$ Ibid., hlm. 5675.
} 


\section{HUKUMAN QISHAS DI ERA MODERN}

\section{1) Sejarah Hukuman Qishas}

Sebelum penulis menguraikan mengenai beberapa permasalahan tersebut, penulis akan menjelaskan bahwa sistem hukuman qishas dalam Islam memang berpedoman pada teks-teks yang ada dalam al-Qur'an yaitu; QS. al-Baqarah (2): 178-179 dan sebuah ayat dalam Kitab Taurat yang diberitakan lagi dalam QS. alMaidah (5): 45. Dengan demikian, bahwa hukuman qishas itu berarti memperlakukan pelaku tindak pidana (الجانى) yang melakukan pembunuhan dan penganiayaan sengaja, dihukum dengan hukuman qishas, yaitu hukuman yang sesuai dengan tindakan kriminal pelaku; nyawa (membunuh) dibalas dengan nyawa, dan anggota badan dengan anggota badan yang sama.

Menurut al-Șabuni bahwa QS. al-Maidah (5): 45 tersebut asbab an-nuzul-nya adalah pada masa Jahiliyah, jika ada seorang hamba dari perkampungan yang terpandang dan disegani itu dibunuh oleh warga dari perkampungan lain, maka pihak perkampungan yang terpandang dan disegani itu berikrar bahwa kami akan membunuh orang merdeka mereka sebagai balasannya, dan jika yang dibunuh itu perempuan, maka mereka berkata bahwa kami akan membunuh laki-laki mereka sebagai balasannya, dan jika yang dibunuh itu lakilaki, maka mereka berkata bahwa kami akan membunuh mereka semua sebagai balasannya. ${ }^{40}$

Berdasarkan QS. al-Maidah (5): 45 di atas, menunjukkan bahwa Islam memberantas tindakan balas dendam yang sangat mengerikan, yang pernah dilakukan oleh orang-orang pada masa Jahiliyah, sehingga dalam ayat di atas dapat dikatakan sebagai batasan tingkat keadilan yang seadil-adilnya.

Hal ini menurut ilmu uṣu al-figh dapat ditetapkan dengan kaidah "الثرع من قبلنا" (syari'at sebelum kita), maka menurut jumbur ulama' Hanafiyyah, Malikiyyah dan Syafi'iyah memandangnya sebagai syari'at yang harus diikuti oleh umat Islam, selama tidak ada dalil yang membatalkannya. Dan sebagian ulama' ada yang mengatakan bahwa bukan sebagai syari'at bagi umat Islam. Sebab

\footnotetext{
40 Al-Sabuni, Muhammad Ali, t.th., Rawail al-Bayan, Tafsir Ayat al-Ahkam, Mesir: Dar alKutub al-“ilmiyah, hlm. 171-172.
} 
syari'at Islam kita adalah menasakh (membatalkan) syari'at yang telah ditetapkan kepada umat sebelum kita. ${ }^{41}$

\section{2) Penerapan Hukuman Qishas-Diyat tidak Mengenal Diskriminasi}

Istinbat hukum ulama' salaf, sebagaimana yang pendapat 'Audah yang digunakan dalam mengkonstruksi jarimah qishas-diyat adalah berdasarkan naș terutama QS. al-Māidah (5): 45 dan QS. alBaqarah (2): 178 adalah sudah tepat. Akan tetapi, yang menjadi permasalahan dan perhatian pada masa sekarang ini (modern) adalah mengenai penerapan hukumannya;

1) Apakah masih diperlukan pembedaan (diskriminasi) hukuman mengenai status sosial dan gender dalam pembunuhan; antara orang merdeka dengan orang merdeka, budak dengan budak, dan perempuan dengan perempuan dalam menetapkan hukuman qishas-diyat.

2) Apakah masih diperlukan diskriminasi agama dalam penetapan hukuman qishas-diyat.

3) Apakah masih diperlukan diskriminasi keluarga dalam penetapan hukuman qishas-diyat.

4) Apakah masih diperlukan diskriminasi gender tentang persaksian dalam penetapan tindak pidana.

5) Apakah masih diperlukan diskriminasi tentang hukuman pembunuhan sekelompok orang atas satu orang.

Berkaitan dengan permasalahan tersebut di atas, maka menurut penulis yang sangat mendesak untuk direkonstruksi adalah sebagai berikut;

1) Orang merdeka membunuh budak, atau laki-laki membunuh perempuan harus tetap di-qishas (tidak ada pembedaan (diskriminasi) mengenai status sosial dan gender dalam penetapan qishas-diyat.

Mengenai ketentuan penetapan hukuman qishas atau diyat yang sejajar (tidak membeda-bedakan) antara orang merdeka dengan merdeka, budak dengan budak (status sosial), dan antara laki-laki dan perempuan (kesetaraan gender) adalah harus

\footnotetext{
41 Yahya, Mukhtar dan Fatchurrahman, 1986, Dasar-Dasar Pembinaan Hukum Fiqh Islami, Bandung: al-Ma'arif, hlm. 116.
} 
dimodifikasi atau disesuaikan dengan dunia Islam modern yang sejalan dengan tuntutan konstitusional dan hak asasi manusia. Jika aturan hukum pidana Islam masih ingin eksis dan sebagai bahan untuk dipertimbangkan di dalam pembuatan perundangundangan suatu negara, maka masalah tersebut harus dihapuskan atau ditinggalkan dalam ketentuan hukum pidana Islam modern. Sebagaimana yang diikuti oleh 'Audah bahwa penjatuhan hukuman qishas-diyat itu harus sesuai (مكافئ) antara status pembunuh dengan terbunuh. Misalnya, jika seorang laki-laki membunuh seorang perempuan, maka tidak dibunuh (di-qishas) seorang laki-laki dan diyatnya adalah separuh diyat laki-laki. ${ }^{2}$ Demikian juga jika seorang merdeka membunuh seorang budak dan non muslim, maka tidak dibunuh seorang merdeka itu dan diyatnya adalah separuh dari diyat seorang merdeka.

Pendapat tersebut berdasarkan Hadits riwayat Abu Dawud: عن عمرو بن شعيب عن أبيه عن جده عن النبى صلى الله عليه وسلم قال: دية Artinya: Dari 'Amru bin Syu'aib dari ayahnya dari kakeknya dari Nabi Muhammad saw. bersabda: "Diyat mu' ahad (kafir simmi) adalah setengah dari diyat orang merdeka".

Hadits riwayat al-Kahlani:

بقوله صلى الله عليه وسلم في حديث معاد: دية المر أة النصف من دية الرجل Artinya: Nabi saw. bersabda di dalam hadïs $M u$ 'ad bahwa diyat seorang perempuan adalah setengah dari diyat laki-laki.

عن عمرو بن شعيب عن أبيه عن جده أن أبا بكر و عمر كان لا لا يقتلان الحر

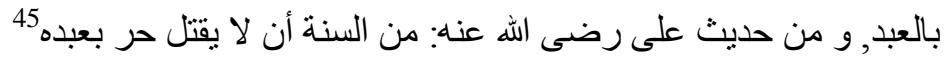

Artinya: Dari 'Amru bin Syu'aib dari ayahnya dari kakeknya babwa Abü Bakar dan Umar keduanya tidak memberikan bukum mati (qișäs) yang dilakukan oleh orang merdeka terbadap orang budak dan hadïs dari 'Alì ra. yang berasal dari al-Sunnah bahwa tidak dibunuh seorang merdeka yang membunub budaknya.

Meskipun beberapa hadits tersebut juga berdasarkan teks QS. al-Baqarah (2): 178 yang menjelaskan bahwa hukuman qishas itu diwajibkan kepada orang-orang yang mempunyai status sosial

42 'Audah, 'Abd al-Qadir, 2011, At-Tasyri' al-Jinai, Jilid II, op cit., hlm. 97.

${ }^{43}$ Dawud, 1988, Sunan Abi Dawnd, op cit, hlm.193.

${ }^{44}$ Al-Kahlani, t.th., Subul as-Salam, op cit, hlm. 250.

${ }^{45} \mathrm{Ibid}$., hlm. 232. 
yang sama, yaitu orang merdeka dengan orang merdeka, budak dengan budak, dan perempuan dengan perempuan, menurut Syaltut QS. al-Baqarah (2): 178 tersebut adalah ayat Madaniyyah yang menyempurnakan ayat Makkiyyah (QS. al-Isra' (17): 33) yang menjelaskan hukuman pembunuhan secara umum, kemudian baru QS. al-Baqarah (2): 178 menjelaskan syarat-syarat dan menguraikannya secara rinci serta menyempurnakan hukumhukumnya. Atau dapat dikatakan bahwa ayat Madaniyyah itu turun dengan membawa hukum khusus sesuai dengan tuntutan kehidupan baru dengan bertambah luasnya perkembangan negeri Islam bercampurnya orang-orang mukmin dengan non mukmin dalam keadaan damai atau perang. ${ }^{46}$

Syaltut mengatakan bahwa ayat Makkiyyah untuk mengobati pengaruh kejahatan pembunuhan di dalam jiwa wali korban sendiri, maka dihibur hatinya akibat penganiayaan berupa pembunuhan atas keluarganya. Oleh karena itu, wali tersebut merupakan orang yang harus dikasihani, mendapat bantuan dari Allah dan manusia, sehingga ia diberi kekuasaan untuk menyembuhkan duka hatinya itu, tetapi dilarang dengan cara-cara yang berlebihan dalam menggunakan kekuasaan itu, dan harus ingat batas-batasnya. Sedapat mungkin memberikan maaf kepada pelakunya, sehingga bentuk kejahatan tersebut bukan al-qishas (pembalasan setimpal), tetapi al-qatl (pembunuhan). Sedangkan dalam ayat Madaniyyah berbunyi: "Wahai orang-orang yang beriman, diwajibkan atas kamu qishas..." di mana hukuman itu disebut qishas, yaitu kata-kata yang mengandung dengan jelas arti keadilan dan persamaan yang wajib dilaksanakannya. Dibukakannya pintu maaf adalah untuk menggerakkan hati manusia, maka disebutlah kata-kata saudara seagama. Demikian itu untuk mendorong supaya bertoleransi dan berlapang dada, mencabut rasa kebencian dari hati kedua belah pihak. Jika setelah itu ternyata mereka mengadakan pembalasan, maka mereka akan diberi siksaan yang pedih. Setelah itu kebijaksanaan Tuhan dalam mensyari'atkan qishas bukan semata-mata untuk keuntungan

\footnotetext{
${ }^{46}$ Syaltut, Mahmud, 1966, al-Islam 'Aqidab wa Syari'ah, op cit, hlm. 340.
} 
korban atau keluarganya, tetapi membentengi masyarakat untuk memelihara suatu kehidupan yang nyata benar. ${ }^{47}$

Adapun arti qishas yang diwajibkan oleh Allah atas kaum muslimin dalam hal pembunuhan, yaitu pembunuhan terhadap pembunuh yang dilakukan tanpa berlebihan, seperti yang dinyatakan oleh ayat Makkiyyah. Ini sesuai dengan apa yang juga diwajibkan oleh Allah dalam Kitab Taurat bahwa "jiwa dibalas dengan jiwa”, sebagaimana dijelaskan QS. al-Maidah (5): 45, yaitu suatu hak yang diakui dalam pembunuhan setiap jiwa yang dilakukan secara sengaja dan aniaya tanpa hak. ${ }^{48}$

Syaltut berpendapat bahwa QS. al-Baqarah (2): 178 telah menyebutkan secara khusus beberapa hal secara terperinci, yaitu; "merdeka dengan merdeka, budak dengan budak, wanita dengan wanita" adalah hanya sebagai penegasan atas pembatalan apa yang mereka lakukan pada zaman jahiliyah yang tidak mencukupkan sekedar membunuh kepada pembunuh saja. Pengkhususan ini bukanlah penjelasan bagi arti "qishas" dalam pembunuhan, karena hal itu sudah jelas tidak membutuhkan penjelasan, sebagaimana menyebutkan sifat-sifat ini bukanlah menjadi dasar bagi wajibnya dilakukan qishas.

Alasan pendapat Syaltut bahwa المفهوم فى النصوص (pengertian di dalam nass) QS. al-Baqarah (2): 178 tidak menunjukkan bahwa tidak boleh dibunuh orang merdeka sebagai pembalasan atas pembunuhan budak, orang laki-laki sebagai pembalasan atas pembunuhan wanita, juga tidak menunjukkan kepada kebalikannya. Oleh karena itu, pengertian yang ada dalam naṣ (المفهوم فى النصوص) harus dipegangi, jika tidak nampak sesuatu maksud dari pengkhususan, kecuali kekhususan mengenai hukum. ${ }^{49}$

Dengan demikian, menurut penulis pemberian hukuman qishas yang masih membedakan status sosial sebagaimana QS. alBaqarah (2): 178, sangat penting untuk ditiadakan, karena sudah tidak relevan dengan kondisi sekarang. Hal tersebut juga kontradiksi dengan spirit QS. an-Nisa' (4): 92, yang mewajibkan

${ }^{47}$ Ibid., hlm. 342-343.

48 Ibid., hlm. 377.

${ }^{49}$ Ibid., hlm. 378. 
kepada pembunuh tidak sengaja untuk memerdekakan budak. Ini berarti secara tidak langsung syari'at Islam menghilangkan atau menghapus perbudakan, sehingga diharapkan pada zaman modern tidak ada lagi perbudakan. Hal ini berdasarkan QS. anNisa': 92;

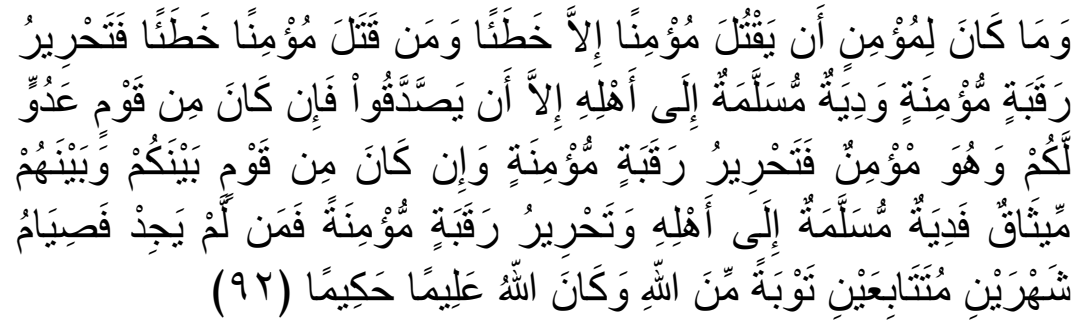

Artinya: Dan tidak layak bagi seorang mukmin membunub seorang mukmin (yang lain), kecuali karena tersalah (tidak sengaja) dan barangsiapa membunuh seorang mukmin karena tersalah (hendaklah) ia memerdekakan seorang hamba sahaya yang beriman serta membayar diyat yang diserabkan kepada keluarganya (si terbunuh itu), kecuali jikea mereka (keluarga terbunub) bersedekah, jika ia (si terbunub) dari kaum (kafir) yang ada perjanjian (damai) antara mereka dengan kamu, maka (hendaklah si pembunub) membayar diyat yang diserabkan kepada keluarganya (si terbunub) serta memerdekakan hamba sahaya yang beriman, barangsiapa yang tidak memperolehnya, maka hendaklah ia (si pembunub) berpuasa dua bulan berturut-turut untuk penerimaan taubat dari pada Allah, dan adalab Allah Maha mengetahui lagi Maha Bijaksana (Depag RI, 1971: 135).

Maksud dari pernyataan: "barangsiapa yang tidak memperolehnya" dalam ayat tersebut adalah tidak mempunyai budak; tidak memperoleh budak yang beriman atau tidak mampu membeli untuk dimerdekakan, maka menurut sebagian ahli tafsir, puasa dua bulan berturut-turut itu adalah sebagai ganti dari pembayaran diyat dan memerdekakan budak. ${ }^{50}$

Oleh karena itu, siapapun yang melakukan pembunuhan harus dijatuhi hukuman yang sama (qishas), meskipun yang ia seorang pimpinan atau majikan dengan seorang bawahan atau pembantunya, atau sebaliknya. Demikian pula, dalam menjatuhkan hukuman qishas tidak boleh membedakan jenis kelamin (diskriminasi gender), siapapun yang membunuh apakah laki-laki membunuh perempuan atau perempuan membunuh laki-laki, jika ia telah terbukti bersalah, maka harus dijatuhi

\footnotetext{
50 Yayasan Penyelenggara Penterjemahan/Pentafsiran al-Qur'an, 1971, Al-Qur'an dan Terjemahannya, Depag RI, hlm. 135.
} 
hukuman qishas. Hal ini sebagaimana Allah swt. telah memberikan hak dan kewajiban yang sama antara laki-laki dan perempuan, tanpa membeda-bedakan jenis kelaminnya. Hal ini berdasarkan QS. Ali 'Imran (3): 195, an-Nisa' (4): 124 dan alHujurat (49): 13;

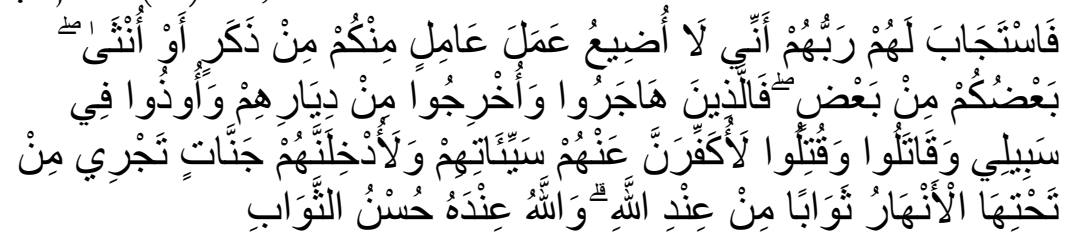

Artinya: Maka Tuban mereka memperkenankan permohonannya (dengan berfirman): Sesunggubnya Aku tidak menyia-nyiakan amal orang-orang yang beramal di antara kamu, baik laki-laki atau perempuan, (karena) sebagian kamu adalah turunan dari sebagian yang lain, maka orang-orang yang berbijrah, yang diusir dari kampung halamannya, yang disakiti pada jalan-Ku yang berperang dan yang dibunuh, pastilah akan Ku-hapuskan kesalahan-kesalahan mereka dan pastilah Aku masukean mereka ke dalam surga yang mengalir sungai-sungai di bawahnya, sebagai pahala di sisi Allah, dan Allah pada sisi-Nya pahala yang baik (Depag RI, 1971: 110).

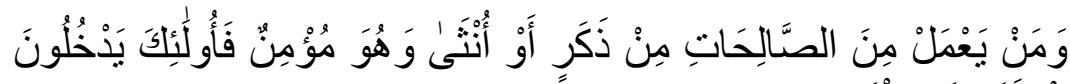

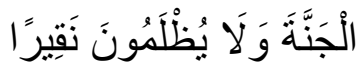

Artinya: Barangsiapa yang mengerjakan amal-amal saleh, baik laki-laki maupun perempuan sedang ia orang yang beriman, maka mereka itu masuk ke dalam surga dan mereka tidak dianiaya walau sedikitpun (Depag RI, 1971: 142).

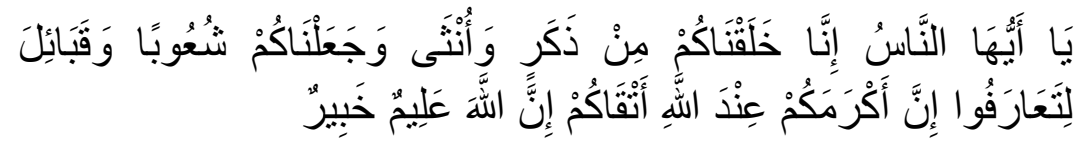

Artinya: Hai manusia, sesunggubnya Kami menciptakan kamu dari seorang lakilaki dan seorang perempuan dan menjadikan kamu berbangsa-bangsa dan bersuku-suku supaya kamu saling kenal-mengenal, sesunggubnya orang yang paling mulia di antara kamu di sisi Allah ialah orang yang paling taqwa di antara kamu, sesunggubnya Allab Maha Mengetabui lagi Maha Mengenal (Depag RI, 1971: 847).

Dari 3 ayat tersebut di atas, dapat dipakai dengan jelas bahwa spirit al-Qur'an tidak membeda-bedakan umatnya dari jenis kelamin, suku bangsa, merdeka, dan budak sebagai status sosialnya.

2) Orang muslim membunuh orang non muslim harus tetap diqishas (tidak ada diskriminasi mengenai agama dalam penetapan qishas-diyat). 
Pada umumnya, praktek hukum sebelum Islam datang berorientasi dan mencerminkan kepentingan elite dari komunitas masyarakat. Ketimpangan semacam itu sesuai dengan kenyataan bahwa struktur masyarakat Arab pra Islam itu, sebenarnya sangat didominasi oleh kaum aristokrat dan borjuis. Hal ini terlihat jelas dalam penerapan hukuman qishas-diyat antara seorang muslim sebagai penguasa dengan non muslim kaum minoritas sebagai musuhnya.

Mengenai diskriminasi agama, mayoritas fuqaba' perintis mengatakan bahwa seorang muslim yang membunuh non muslim tidak dijatuhi hukuman qishas, misalnya, asy-Syafi'i ${ }^{\circ}$ pada saat itu mensyaratkan adanya kesetaraan dua darah (تتكافأ الذميين) dalam status kemerdekaan dan status agama bagi penjatuhan hukuman qishas, sebagaimana Rasulullah saw. bersabda: "Seorang muslim itu sederajat darahnya dengan seorang muslim dan seorang ìimmi, tidak dibunub seorang mukmin membunuh seorang kafir" Jika seorang merdeka membunuh seorang budak, atau seorang muslim membunuh seorang non muslim, maka menurutnya tidak ada hukuman qishas. ${ }^{51}$ Pendapat ini masih diikuti oleh mayoritas fuqaha'.

Abu Hanifah berbeda pendapat dengan mayoritas fuqaba' bahwa ia tidak mensyaratkan تتكافأ الذميين dalam masalah penjatuhan hukuman qishas, maka siapapun yang terbukti membunuh harus dijatuhi hukuman qishas. Hal ini didasarkan kepada keumuman hukuman qishas, sebagaimana dalam QS. alBaqarah (2): 178. dan QS. al-Maidah (5): 45. ${ }^{52}$ Akan tetapi, pendapat Abu Hanifah tersebut tidak diterima oleh 'Audah.

Oleh karena itu, penulis sepakat dengan pendapat Abu Hanifah yang telah sesuai dengan tuntutan konstitusional Negara modern, yang tidak membedakan status kemerdekaan dan status agama terhadap si pelaku kejahatan pembunuhan. Mengenai kebijakan hak (kewenangan) pemberian hukuman atau memaafkan hukuman qishas yang disebut dengan istilah "ولى الدم" "ولى", menurut Imam Malik bin Anas,"adalah para ahli waris dari pihak laki-laki saja, demikian juga pendapat imam asy-Syafi' $i$.

51 'Audah, 'Abd al-Qadir, 2011, At-Tasyri' al-Jinai, Jilid II, op cit., hlm. 99.

${ }^{52}$ Ibid. 
Sedangkan Imam Abu Hanifah berpendapat bahwa "ولى الدم" adalah ahli waris korban, baik dari pihak laki-laki maupun dari pihak perempuan. ${ }^{53}$

Ketentuan hukuman qishas dalam hukum pidana Islam oleh para fuqaha' perintis sebagaimana yang diikuti oleh 'Audah juga masih membeda-bedakan antara pembunuhan seorang muslim atas non muslim (kafir) tidak kafir غimmi atau mu'ahad, maka pembunuh jika membunuh orang non muslim tidak dapat dijatuhi hukuman qishas, ${ }^{54}$ berdasarkan hadits riwayat Abu Dawud, at-Tirmizi \& al-Kahlani;

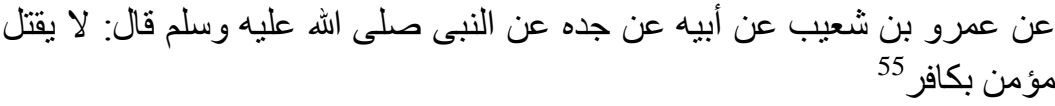

Artinya: Dari 'Amru bin Syu 'aib dari ayahnya dari kakeknya dari Nabi saw. bersabda: "Orang muslim tidak boleh dibunuh (di-qishas), karena membunuh orang kafir".

Menurut hemat penulis, eksistensi Hadits tersebut di atas sangat perlu untuk dipertimbangkan, karena berpijak atas rasa keadilan dan persamaan hak di muka hukum, seorang muslim yang membunuh dengan sengaja terhadap seorang non muslim, baik ia kafir maupun kafir żimmi atau mu'ahad (ada perjanjian dengan Islam), harus dijatuhi hukuman qishas, jika keluarga terbunuh tidak memaafkan. Penulis sependapat dengan Abu Hanifah yang dikutip al-Mawardi, ${ }^{56}$ dan dikuatkan oleh Mahmud Syaltut bahwa seorang muslim yang membunuh dengan sengaja terhadap seorang non muslim harus dikenakan hukuman qishas. Ini didasarkan kepada keumuman hukuman qishas, yang terdapat dalam QS. al-Baqarah (2): 178. dan al-Maidah (5): 45. ${ }^{57}$

Dalam masalah tersebut, istinbat hukum Syaltūt dalam berijtihad adalah beralasan bahwa QS. al-Baqarah (2): 178 dalam teks: كتب عليكم القصاص فى القتلى memberikan pemahaman adanya persamaan dalam melakukan pembalasan. Lebih lanjut ia memperkuat argumentasinya bahwa perintah kepada mereka

53 Al-Mawardi, 1970, Al-Ahkeam as-Sultaniyyah, op cit, hlm. 231.

54 'Audah, 'Abd al-Qadir, 2011, At-Tasyri' al-Jinai, Jilid II, op cit., hlm. 97-100.

${ }_{55}$ Dawud, 1988, Sunan Abi Dawud, op cit, hlm. 171, At-Tirmiżi, t.th., al-Jami aș-Sahih, Juz IV, op cit, hlm. 17. Dan Al-Kahlani, t.th., Subul as-Salam, op cit, hlm, 233.

56 Al-Mawardi, 1970, Al-Ahkam as-Sultaniyyah, op cit, hlm. 231.

57 Syaltut, Mahmud, 1966, al-Islam 'Aqidah wa Syari'ah, op cit, hlm. 382. 
(kaum mukmin) untuk menjalankan hukuman qishas dalam pembunuhan, tidak ada kaitannya dengan iman seseorang yang terbunuh atau kekafirannya. ${ }^{58}$

Syaltut menegaskan bahwa arti persaudaraan yang terkandung dalam QS. al-Baqarah (2) :178 tersebut tidak harus berarti saudara dalam satu agama (keimanan) saja, tetapi boleh dengan pengertian yang luas, yaitu saudara sesama manusia, bukankah manusia ini seluruhnya dari keturunan Adam. ${ }^{59}$ Syaltut lebih berpegang pada ayat-ayat yang menyuruh untuk berbuat adil, yaitu. QS. al-Maidah (5): 8 menegaskan;

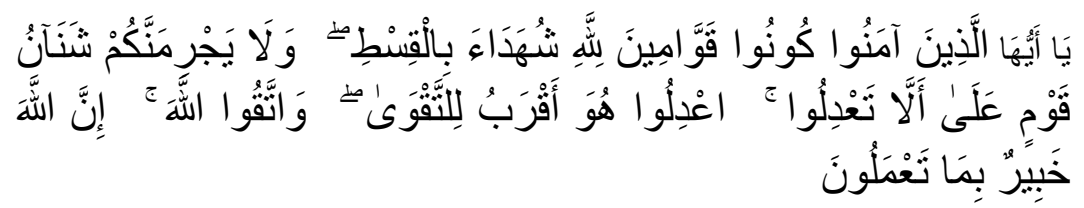

Artinya: Hai orang-orang yang beriman hendaklah kamu jadi orang-orang yang selalu menegakkan (kebenaran) karena Allah, menjadi saksi dengan adil dan janganlah sekali-kali kebencianmu terbadap sesuatu kaum, mendorong kamu untuk berlaku tidak adil, berlaku adillah, karena adil itu lebih dekat kepada takwa dan bertakwalah kepada Allah, sesunggubnya Allab Maba Mengetahui apa yang kamu kerjakan (Depag RI, 1971: 159).

Ayat tersebut di atas menurut Syaltut, keadilan itu bersifat universal tidak dibatasi oleh sekat-sekat kemasyarakatn maupun sosial keagamaan atau atribut-atribut lainnya. ${ }^{60}$ Ini berbeda dengan An-Na'im yang mengatakan bahwa semua aspek syari'ah historis yang berhubungan dengan non Islam adalah melanggar prinsip-prinsip persamaan di depan hukum. Jika seorang muslim membunuh seorang non muslim, maka seorang muslim tersebut tidak dibunuh, karena dianggapnya bahwa non muslim tidak sama/sebanding (al-musamah) dengan seorang muslim. Demikian juga dalam masalah pembayaran diyat kepada non muslim lebih rendah daripada pemberian diyat kepada seorang muslim. ${ }^{61}$

Oleh karena itu, menurut penulis bahwa berbagai implikasi diskriminasi tersebut jelas mengandung konsekuensi psikologis

\footnotetext{
${ }^{58}$ Ibid., hlm. 384.

${ }^{59}$ Ibid.

${ }^{60}$ Ibid. hlm. 382.

${ }^{61}$ An-Na'im, Abdullah Ahmed, 1997, Dekonstruksi Syari ah: op cit, hlm. 173.
} 
dan sosial yang mencolok, sehingga ketentuan tersebut harus dipertimbangkan atau bahkan wajib dihilangkan.

3) Orang tua membunuh anaknya atau anak membunuh orang tuanya tetap (harus) di-qishas (tidak ada diskriminasi keluarga dalam penetapan hukuman qishas.

Menurut jumbur 'ulama' (Abu Hanifah, asy-Syafi'i dan Aḥmad) sebagaimana diikuti 'Audah bahwa ketentuan penetapan hukuman qishas yang tidak bisa dilaksanakan adalah jika orang tua membunuh anaknya, maka ayah yang membunuh anaknya tidak dikenakan hukuman qishas, tetapi hanya dengan hukuman ta 'air. ${ }^{62}$

Pendapat jumbur ulama', berdasarkan hadits riwayat atTirmiżi dan al-Kahlānī:

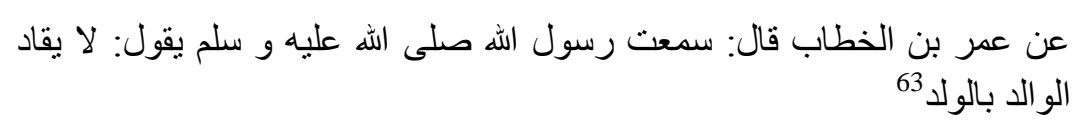

Artinya: Dari Umar bin al-Khațāab berkata; saya mendengar Rasulullah saw. bersabda: "Tidak di-qishas orang tua yang membunub anaknya".

عن ابن عباس عن النبي صلى الله عليه و سلم قال: لا يقتل الو الد بالولد 64 الد Artinya: Dari Ibnu 'Abbās dari Nabi saw. bersabda: "Tidak dibunuh orang tua yang membunub anaknya".

Dan Hadits riwayat Ibnu Majah:

عن عبد الله ابن عمرو قال: قال رسول الله صلى الله عليه و سلم: أنت و ماللك

Artinya: Dari 'Abdillāh Ibnu 'Amru berkata: Rasulullah saw. bersabda: "Kamu dan hartamu itu adalab milik bapakmu".

Berdasarkan Hadits tersebut di atas menurut 'Audah, jumbür berpendapat bahwa hukuman qishas tidak dijatuhkan terhadap seorang bapak atau orang tua yang membunuh anaknya, karena membunuh anaknya mengandung unsur syubhat (tidak ada sandaran hukum yang jelas) di dalamnya, sehingga harus dihindari. ${ }^{66}$

\footnotetext{
62 'Audah, 'Abd al-Qadir, 2011, At-Tasyri' al-Jinai, Jilid II, op cit., hlm. 93.

${ }^{63}$ At-Tirmizi, t.th., al-Jami` aș-Șahih op cit, hlm. 12.

${ }^{64}$ al-Kahlani, t.th., Subul as-Salam, op cit, hlm, 233.

${ }^{65}$ Ibnu Majah, t.th., Sunan Ibnu Majah, Juz II, Beirut-Libanon: Dar al-Kutub al-'Ilmiyyah hlm. 769.

66 'Audah, 'Abd al-Qadir, 2011, At-Tasyri' al-Jinai, Jilid II, op cit., hlm. 93.
} 
Pernyataan tersebut di atas dikuatkan Syaltut bahwa orang tua yang membunuh anaknya tetap dikenakan hukuman qishas secara mutlak. ${ }^{67}$ Istinbat hukum yang digunakan Syaltut adalah dalil mengenai keumuman ayat qishas QS. al-Baqarah (2): 178 dan pelaksanaan ayat tersebut sesuai dengan ayat-ayat yang memerintahkan untuk berbuat adil kepada siapapun termasuk kepada kelurganya, di antaranya QS. al-Maidah (5): 8.

Dengan ditetapkan hukuman qishas terhadap seorang ayah yang membunuh anaknya akan memberikan rasa keadilan dan sesuai dengan tujuan hukuman itu sendiri, yaitu;

1) Menjaga keutamaan dan melindungi masyarakat dari kehinaan, dan untuk dapat mencapai kemaslahatan secara umum. ${ }^{68}$

2) Di samping itu juga mempunyai nilai preventif dan edukatif bagi kelompok masyarakat. ${ }^{69}$

Syaltut menyatakan bahwa orang tua tidak diqishas karena membunuh anaknya, majikan (tuan, pejabat, atau atasannya) tidak diqishas karena membunuh hambanya (budak, batur atau pesuruhnya). Orang merdeka tidak diqishas karena membunuh budaknya, seorang laki-laki tidak diqishas karena membunuh seorang perempuan dan orang Islam tidak diqishas karena membunuh orang non muslim, itu semua sebenarnya tidak sesuai dengan prinsip-prinsip umum syari'ah yang ada dalam syari'at Islam. Dengan demikian, berdasarkan materi hukum dan semangat perundang-undangan, hukuman qishas harus berlaku terhadap semua orang tanpa ada diskriminasi.$^{70}$

4) Persaksian laki-laki dan perempuan adalah sama (tidak ada diskriminasi gender tentang persaksian dalam penetapan perdata dan tindak pidana).

Jika mengacu pada prinsip umum syari'ah yang didasarkan kepada beberapa ayat al-Qur'an, nilai kesaksian perempuan setengah dari kesaksian nilai laki-laki berdasarkan QS. al-Baqarah (2): 282 menyatakan:

\footnotetext{
${ }^{67}$ Syaltut, Maḥmud, 1966, al-Islam 'Aqidah wa Syari'ah, op cit, hlm. 380.

${ }^{68}$ Zahrah, al-Imam Muhammad Abū, t.th., al-'Uqubah, Mesir: Dār al-Fikr al-'Arabī, hlm. 33.

69 'Audah, 'Abd al-Qadir, 2011, At-Tasyri' al-jinai, Jilid I, op cit., hlm. 610-611.

${ }^{70}$ Syaltut, Maḥmud, 1966, al-Islam 'Aqidah wa Syari'ah, op cit, hlm. 322.
} 


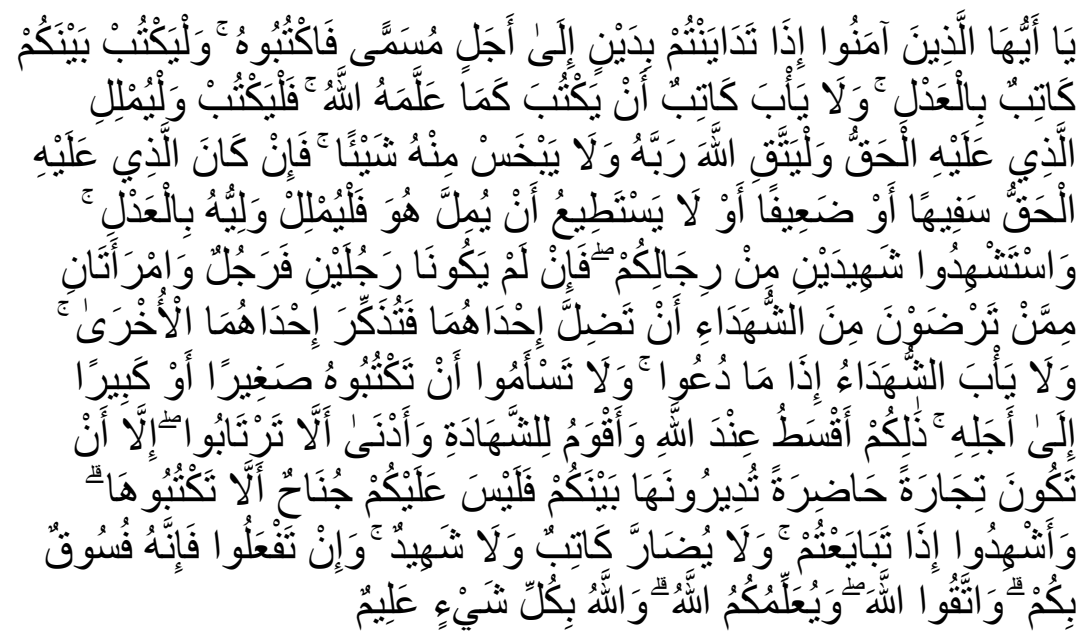

Artinya: Hai orang-orang yang beriman, apabila kamu bermuamalah tidak secara tunai untuk. waktu yang ditentukan, hendaklab kamu menuliskan-nya, dan hendaklah seorang penulis di antara kamu menuliskannya dengan benar, dan janganlah penulis enggan menuliskannya sebagaimana Allah mengajarkan-nya, maka bendaklah ia menulis, dan hendaklah orang yang berhutang itu mengimlake.en (apa yang akan ditulis itu), dan hendaklah ia bertakwa kepada Allah Tuhannya, dan janganlah ia mengurangi sedikitpun daripada butangnya, jika yang berhutang itu orang yang lemah akalnya atau lemah (keadaannya) atau dia sendiri tidak mampu mengimlakkan, maka bendaklah walinya mengimlakekan dengan jujur, dan persaksikanlah dengan dua orang saksi dari orang-orang laki-laki (di antaramu), jika tak ada dua orang laki-laki, maka (boleh) seorang laki-laki dan dua orang perempuan dari saksi-saksi yang kamu ridhai, supaya jika seorang lupa, maka yang seorang mengingatkannya, janganlah saksi-saksi itu enggan (memberi keterangan) apabila mereka dipanggil... (Depag RI, 1971: 70).

Berdasarkan ayat tersebut, terutama teks yang artinya; "jikea tidak ada dua orang laki-laki, maka (boleh) seorang laki-laki dan dua orang perempuan dari saksi-saksi yang kamu ridhai, supaya jika seorang lupa, maka yang seorang mengingatkannya", ternyata beberapa ayat alQur'an masih mengikuti budaya Arab yang masih memandang sebelah mata mengenai kemampuan seorang perempuan, hal tersebut memang tidak bisa dipungkiri bahwa pada saat abad ke7 Masehi, perempuan-perempuan pada umumnya belum berpendidikan sebagaimana laki-laki. Akan tetapi, menurut penulis bahwa beberapa ketentuan umum syari'ah yang masih diskriminatif tersebut harus dihilangkan, karena pada kenyataannya tidak semua kemampuan perempuan selalu lebih rendah dari laki-laki. 
Pendapat penulis menggarisbawahi pernyataan Syaltut bahwa misi dari ayat tersebut, yaitu QS.al-Baqarah (2): 282 adalah berkaitan dengan soal kepercayaan mengenai transaksi utang piutang, bukan berkaitan dengan persoalan di depan pengadilan. Ayat tersebut juga memberikan cara dan jalan yang sebaikbaiknya untuk mendapatkan kepercayaan dari para pihak yang melakukan transaksi. Mengenai disebutkan dalam ayat tersebut, yaitu seorang laki-laki dan dua orang perempuan, karena saat itu (secara sosiologis) perempuan tidak terbiasa terjun dalam perniagaan, sehingga daya ingatnya dikhawatirkan agak lemah dibandingkan dengan laki-laki yang saat itu menekuninya. Syaltut menegaskan bahwa al-Qur'an diwahyukan pada saat itu kaum perempuan tidak lazim aktif dalam berbagai transaksi finansial dan kurang akrab dengan masalah perniagaan di banding dengan kaum laki-laki. Oleh karenanya daya ingat kaum perempuan itu dalam urusan keuangan lemah, sebaliknya dalam urusan rumah tangga perempuan lebih unggul. Sudah menjadi watak manusia pada umumnya bahwa daya ingatnya itu kuat dalam persoalan yang sedang ditekuninya, berkonsentrasi dan terlibat di dalamnya. Syaltūt menegaskan lagi bahwa jika kaum perempuan itu berada dalam posisi dan tradisi ikut terlibat dalam urusan perdagangan, keuangan, transaksi utang piutang dan lembaga peradilan, maka tentu saja mereka berhak untuk disejajarkan dan mendapatkan kepercayaan dalam kesaksian sebagaimana kepercayaan yang diperoleh seorang laki-laki. ${ }^{71}$

Mengenai saksi dalam penetapan perzinaan (pidana) 'Audah mendasarkan kepada QS. al-Baqarah (2): 282 yang mensyaratkan bahwa saksi dalam perzinaan harus ada 4 (empat) orang laki-laki semua, jika tidak ada, maka nilainya seorang lakilaki sama dengan dua orang perempuan. Ia beralasan bahwa kesaksian perempuan adalah syubhat (samar-samar atau masih dalam keraguan), dan perkara syubhat dilarang untuk menetapkan hukuman hudud, karenanya bersikap hati-hati (ikbiyat) itu adalah wajib hukumnya di dalam masalah hudud. Pendapat 'Audah

\footnotetext{
${ }^{71}$ Ibid., hlm. 248-250.
} 
berdasarkan kaidah; أن الحدود تدر أ بالثبهات artinya: bahwa hukuman (al-hudud) harus ditinggalkan/dihindari karena samar-samar. ${ }^{72}$

Meminjam istilah dari Abd. Salam Arief, yang menyimpulkan bahwa para ulama' perintis termasuk 'Audah menjadikan ayat-ayat yang semestinya bersifat sosiologis telah dipatenkan menjadi ayat-ayat teologis yang bersifat absolut. Menurut penulis, masalah persaksian ini harus sama antara lakilaki dan perempuan dalam ketentuan hukum pidana Islam modern. ${ }^{73}$

Inilah yang menjadi keprihatinan dan perhatian $\mathrm{An}-\mathrm{Na}$ 'im bahwa hukum syari'ah tentang pembuktian masih membedabedakan saksi berdasarkan jenis kelamin dan agama. Sementara tidak ada batasan apapun bagi saksi laki-laki muslim yang dianggap selalu berlaku adil dalam kesaksiannya menurut syari $^{6} a{ }^{74}{ }^{74}$

5) Pembunuhan massal terhadap seorang tetap (harus) diqishas (tidak ada diskriminasi pembunuhan sekelompok orang atas seorang dalam penetapan hukuman qishas.

Pembunuhan yang dilakukan oleh sekelompok orang atau secara bersama-sama terhadap seorang diri, menurut pendapat jumbur ulama' (Malik, asy-Syafi'i dan Aḥmad), pembalasannya adalah pembunuhan atas mereka itu semua sebagai pembalasan atas pembunuhan satu orang saja di antara mereka. Hal ini sebagaimana yang diikuti oleh 'Audah bahwa القصاس من الجماعة للواحد, artinya: hukuman qishas terhadap sekelompok orang adalah hanya satu orang saja. Alasan jumbur adalah bahwa kesaksian mereka semua itu hanya diterima satu saja sebagai kesaksiannya. ${ }^{75}$

Hemat penulis harus tetap dihukumi qishas bagi semua orang yang terlibat dalam pembunuhan tersebut, berdasarkan ijma ${ }^{\text {sahabat. }}{ }^{76} \mathrm{Jika}$ hal tersebut tidak ditetapkan hukuman qishas, bisa terjadi preseden buruk bahwa pada kenyataannya banyak orang yang mengadakan pembunuhan terhadap seseorang yang

\footnotetext{
72 'Audah, 'Abd al-Qadir, 2011, At-Tasyri' al-Jinai, Jilid II, op cit., hlm. 338-339.

73 Arief, Abd. Salam, 2003, Pembaruan Pemikiran Hukum Islam Antara Fakta dan Realita (Kajian Pemikiran Hukum Syaikh Mahmud Syaltut), Yogyakarta: LESFI, hlm. 104.

74 An-Na'im, Abdullah Ahmed, 1997, Dekonstruksi Syariab: op cit, hlm. 174.

75 'Audah, 'Abd al-Qadir, 2011, At-Tasyri' al-Jinai, Jilid II, op cit., hlm. 177.

${ }^{76}$ Syaltut, Maḥmud, 1966, al-Islam 'Aqidah wa Syari'ah, op cit, hlm. 381.
} 
dilakukan secara bersama-sama, dengan tujuan agar mereka tidak dapat dijatuhi hukuman qishas secara bersama-sama.

Ini sejalan dengan pemikiran Syaltut yang menjelaskan bahwa 'Umar ra. telah membunuh 7 (tujuh) orang laki-laki dari penduduk San'a yang telah membunuh seorang laki-laki dan 'Umar ra. berkata: "Sekiranya penduduk San'a membunuhnya secara bersama-sama, maka akan saya bunuh mereka semua". ${ }^{77}$ Pada saat itu, tidak ada seorangpun yang membantah putusan tersebut, karena itu menurut Syaltūt dapat dikatakan bahwa putusan itu merupakan ijma'. Hukuman itu bukanlah sekedar berdasarkan kepada arti ayat saja, tetapi juga karena maksud dari teks (nas) itu sendiri, yaitu bahwa qishas bukanlah berarti pembalasan satu jiwa dibalas satu jiwa, tetapi qishas itu adalah membunuh pembunuh. Pembunuh itu mungkin satu orang dan mungkin banyak orang, dan kewenangan menuntut juga diberikan oleh Allah kepada wali korban telah mengatur tentang pembunuhan, tidak disebutkan pembunuh itu seorang atau lebih. $^{78}$

Menurut Syaltut bahwa agama Islam ini diturunkan untuk kepentingan (kemaslahatan) manusia, baik untuk kehidupan di dunia maupun di akherat, sebagaimana ia menyatakan;

فما كان الإسلام إلا دينا يراد به تدبير مصالح العباد و تحقيق العدالة وحفظ

Artinya: Islam itu semata-mata agama yang dikehendaki darinya pengaturan mengenai kemaslabatan manusia, merealisir keadilan dan untuk menjaga bakhake (seseorang).

Kemudian Syaltut menegaskan bahwa:

$$
\text { الإجنهاد الذى يتغير تبعا للمصلحة } 80
$$

Artinya: Ijtihad itu berubah disesuaikan dengan kemaslahatan yang ada.

Di sini terlihat jelas, bahwa Syaltut meletakkan nilai-nilai kemanusiaan sebagai prinsip kehidupan yang harus dihargai dan pandangan ini sejalan dengan prinsip-prinsip المصالح الخمسة dang dicetuskan oleh asy-Syaṭibi dengan istilah مجموع الضروريات salah

${ }^{77}$ Ibid.

${ }^{78}$ Ibid.

${ }^{79}$ Ibid., hlm. 491.

${ }^{80}$ Ibid., hlm. 505. 
satu dari prinsipnya adalah hifd al-nafs (حفظ النفس). ${ }^{81}$ Hal ini sesuai kaidah yang dirumuskan oleh Ibnu Qayyim al-Jauziyyah:

تغير الفتوى و اختلافها بحسب تغير الأزمنة و الأمكنة الأحوال والنية والعوائد82

Artinya: Berubah dan berbedanya fatwa itu sesuai dengan perubahan zaman, tempat, kondisi sosial, niat (kemanan) dan adat istiadat yang berlaku.

\section{KESIMPULAN}

Berdasarkan uraian di atas, penerapan hukuman pembunuhan dalam hukum pidana Islam tidak hanya berdasarkan nash al-Qur'an dan alHadits secara letterlejk (apa adanya) semata-mata yang hanya dipahami sebagai hukum yang berlaku secara normative sebagai ayat-ayat teologis yang bersifat absolut, tetapi harus memperhatikan juga aspek-aspek, historis-sosiologis, perkembangan zaman sebagai tuntutan konstitusional dan hak asasi manusia. Hal ini penulis tidak mempunyai maksud apa-apa kecuali untuk membela dan mempertahankan eksistensi hukum pidana Islam yang lebih aplikatif, elastis, tidak melangit atau ketentuannya membumi dan dapat diterima oleh masyarakat modern, sehingga memungkinkan sebagai bahan pertimbangan sumber-sumber hukum pidana modern.

\footnotetext{
81 Asy-Syațibi, Abi Isḥaq, 2004, al-Muwafaqat fi Ușul asy-Syaríah, Beirut-Libanon: Dar alKutub al-'Ilmiyyah, hlm. 222.

${ }^{82}$ Ibnu Qayyim al-Jauziyyah, t.th., I'lam al-Muwaqi'in, Beirut-Libanon: Dar al-Kutub al'Ilmiyyah, hlm. 1.
} 


\section{DAFTAR PUSTAKA}

'Audah, 'Abd al-Qadir, 2011, Al-Tasyri' al-Jina'i al-Islami Muqaranan bi Qanun al-Wadli, Juz I dan II, Beirut-Libanon: Dar al-Kutub al'Ilmiyyah.

Abu Hafsin, 2010, Kontribusi Konsep Keadilan Hukum Pidana Islam Terhadap Pengembangan Konsep Keadilan Hukum Pidana Positif, Semarang: IAIN Walisongo.

Al-Bukhari al-Ja'fy, Imam Abi 'Abdillah Muhammad bin Isma'il Ibn Ibrahim bin al-Mughirah bin Bardzabah, 1992, Shahih al-Bukhari, Juz VIII, Beirut-Libanon: Dar al-Kutub al-'Ilmiyyah.

Al-Kahlani, Muḥammad bin Isma'il, t.th., Subul al-Salam, Syarb Bulugh alMaram: min Adilah al-Abkam, Juz III, Beirut: Dar al-Fikr.

Al-Mawardi, Abi al-Hasan 'Ali bin Muhammad bin Habib al-Baṣri alBagdadi, 1970, Al-Ahkeam as-Sultaniyyah wa al-Walayat ad-Diniyyah, Mesir: Dar al-Fikr.

Al-Sabuni, Muhammad Ali, t.th., Rawail al-Bayan, Tafsir Ayat al-Abkam, Beirut-Libanon: Dar al-Kutub al-'Tlmiyyah.

Al-Tirmidzi, Abi 'Isa Muḥammad bin 'Isa bin Saurah, t.th., al-Jami' alShaḥh, Juz IV, Beirut-Libanon: Dar al-Kutub al-'Ilmiyyah.

An-Na'īm, Abdullah Ahmed, 1997, Dekonstruksi Syari'ah: Wacana Kebebasan Sipil, Hak Asasi Manusia dan Hubungan Internasional dalam Islam, Yogyakarta: LKiS Yogyakarta.

Arief, Abd. Salam, 2003, Pembaruan Pemikiran Hukum Islam Antara Fakta dan Realita (Kajian Pemikiran Hukum Syaikh Mahmud Syaltut), Yogyakarta: LESFI.

Asy-Syațibi, Abi Isḥaq, 2004, al-Muwafaqat fi Ușul asy-Syari'ah, BeirutLibanon: Dar al-Kutub al-'Ilmiyyah.

Az-Zuhaili, Wahbah, 2002, Al-Fiqh al-Islami wa Adilatubu, Juz VII, Damaskus: Dar al-Fikr.

Dawud, al-Imam al-Hafidz al-Muṣannif al-Mutqan Abi Dawud Sulaiman ibn al-Asy'ás al-Sajastan̄̄ al-Azdi, 1988, Sunan Abi Dawud, Juz IV, t.tp.: al-Dar al-Mișriyyah al-Libaniyyah

Ibn Majah, Abi 'Abdillah Muhammad bin Yazid al-Qazwini, t.th., Sunan Ibnu Majah, Juz II, Beirut: Dar al-Fikr.

Ibnu Qayyim al-Jauziyyah, t.th., I'lam al-Muwaqi'in, Beirut-Libanon: Dar al-Kutub al-Ilmiyah. 
Ibnu Rusyd, al-Imam Abi al-Walid Muhammad bin Aḥmad bin Muḥammad bin Aḥmad bin Rusyd al-Qurțubi, 1988, Bidayah alMujtahid Wa Nihayah al-Muqtașid, Juz II, Beirut-Libanon: Dar alKutub al-'Ilmiyyah.

Khallaf, 'Abd al-Wahhab, 1972, Tlmu Ushul al-Figh, Jakarta-Indonesia: alMajlis al-'Ala al-Indonesi li al-Da'wah al-Islamiyyah.

Muladi dan Barda Nawawi Arief, 2005, Teori-Teori dan Kebijakan Pidana, Bandung; PT. Alumni.

Muslim, al-Imām Abī al-Husain Muslim bin al-Hajjāij al-Qusyairī anNaisābūrī, 1983, Șahịh Muslim, Juz III, Beirūt-Libanon: Dār al-Fikr. Ridho, Achmad Ainur, 2010, Hermeneutika Qur'an Versi Amina Wadud Muhsin, dalam Hermeneutika al-Qur'an dan Hadits, editor; Sahiron Syamsuddin, Yogyakarta: elSAq Press.

Unais, Ibrahim, et.al, t.th. al-Mu'jam al-Wäsiț, Juz II, t.tp.: Dār Ihya at-Turās al-'Arabī.

Yahya, Mukhtar dan Fatchurrahman, 1986, Dasar-Dasar Pembinaan Hukum Figh Islami, Bandung: al-Ma'arif.

Yayasan Penyelenggara Penterjemahan/Pentafsiran al-Qur'an, 1971, AlQur'an dan Terjemahannya, Depag RI.

Zahrah, al-Imām Muḥammad Abū, t.th., al-Jarimah wa al-Uqübah, Mesir: Dār al-Fikr al-'Arabī. 